\title{
Upper Llandovery-Wenlock (Silurian) palynology of the Pentland Hills inliers, Midland Valley of Scotland
}

\author{
S. G. MOLYNEUX ${ }^{1}$, H. F. BARRON ${ }^{2}$ and R. A. SMITH ${ }^{2}$ \\ ${ }^{1}$ British Geological Survey, Keyworth, Nottingham NG12 5GG, U.K. (e-mail: sgm@bgs.ac.uk) \\ ${ }^{2}$ British Geological Survey, Murchison House, West Mains Road, Edinburgh EH9 3LA, U.K.
}




\section{Synopsis}

The results of a palynological study on late Llandovery-Wenlock (mid Silurian) successions in the North Esk, Bavelaw Castle and Loganlee inliers of the Pentland Hills, Midland Valley of Scotland, are documented. Palynological assemblages from the Reservoir Formation are dominated by acritarchs, but chitinozoa, cryptospores and scolecodonts are also present. Assemblages from the lower part of the Reservoir Formation are of low diversity and abundance, but marked increases in both abundance and diversity, particularly of the acritarchs, occur in the upper $200 \mathrm{~m}$ or so of the formation. The reasons for the marked increases are unclear, but could reflect changing environmental conditions during deposition of the upper Reservoir Formation, with the marine palynomorphs tracking changes in the location of certain physical and chemical properties of water-masses, for example nutrient availability, salinity or temperature. There is a general decline in the abundance and diversity of acritarchs and chitinozoans above the Reservoir Formation, although both groups, together with rare cryptospores, are present in samples from the Deerhope and Wether Law Linn formations. The Henshaw Formation yielded few marine microfossils, but more abundant and diverse spores and cyptospores than the underlying formations, consistent with an upward transition from marine to prograding terrestrial facies. The microfloras from the Reservoir, Deerhope and Wether Law Linn formations are consistent with the late Llandovery age indicated by graptolite evidence.

A feature of assemblages from the Reservoir Formation, particularly the more productive samples from the upper part of the formation, is the common occurrence of sphaeromorph acritarchs, Moyeria cabottii and Tylotopalla species. The common occurrence of these forms gives the palynological assemblages a distinctive character. Similar sphaeromorph-MoyeriaTylotopalla dominated acritarch microfloras occur at about the same level (spiralis Graptolite Biozone) in the Silurian succession of the Girvan Inlier, in the Drumyork Flags Formation. They might therefore be useful for correlating upper Llandovery rocks across the Midland Valley.

\section{Introduction}

The Middle Ordovician to Silurian sedimentary successions of the Midland Valley and Southern Uplands of Scotland record the evolution of an active plate margin between Laurentia and Iapetus following the Grampian Orogeny (early to mid-Ordovician). The Silurian successions in Midland Valley inliers (Fig. 1) demonstrate the progressive infilling of a Llandovery to Wenlock inter-arc basin, and record a transition from transgressive marine Llandovery sequences to prograding terrestrial Lower Wenlock successions (Rolfe 1960, 1961; 
Cocks \& Toghill 1973; Cameron \& Stephenson 1985; Robertson 1989; Clarkson et al. 2001). Significant differences in lithologies and thicknesses between the inliers (Fig. 2) suggest the presence of local sub-basins with different histories of sedimentation. The sub-basins probably developed under a sinistral strike-slip regime on the southern continental margin of Laurentia (Smith 1995; Williams \& Harper 1988), trending obliquely to the Southern Upland Fault. Local unconformities in the Llandovery successions of the Girvan area are believed to be the result of block rotation and oblique-slip (Williams \& Harper 1988).

The tectonic evolution of the Midland Valley of Scotland during the Lower Palaeozoic and its setting in Caledonide terrane models have been the focus of much recent debate (Phillips et al. 1998, 2004; Smith 1995; McKerrow et al. 1991; Williams \& Harper 1988). Central to this debate are the palaeontological, sedimentological and structural data from the Silurian rocks of the inliers along the southern margin of the Midland Valley (Fig. 1) and its continuation into Ireland. The Llandovery marine facies in the inliers have yielded graptolite and shelly faunas, both of which have been used in biostratigraphical dating and correlation of the successions. Marine and non-marine palynomorphs are also present, but although terrestrial palynomorphs and associated plant microfossils (cryptospores, miospores, filaments, tubular structures and cuticle) have been documented from several of the inliers aligned close to the southern margin of the Midland Valley (Wellman \& Richardson 1993; Wellman 1995), there are few published accounts of the marine palynomorphs (acritarchs, chitinozoa), and those that have been published have focussed on the Girvan succession (Dorning 1982; Vandenbroucke et al. 2003).

This paper describes palynological assemblages from the Silurian succession in the North Esk Inlier of the Pentland Hills (Figs 1,3), supplemented by limited information from the Bavelaw Castle and Loganlee inliers (Figs 1,4) of the Pentland Hills, and from the Girvan Silurian succession. The main focus has been on the acritarch component of the assemblages, although spores and chitinozoans were also recorded. The palynological investigation was carried out in conjunction with BGS mapping in the Midland Valley.

\section{Silurian succession in the Pentland Hills}

The central Pentland Hills are underlain by steeply dipping or overturned Silurian strata of the North Esk Group (Tipper 1976), which crops out in the North Esk, Bavelaw Castle and Loganlee inliers (Fig. 1). These rocks, of late Llandovery to early Wenlock age, are unconformably overlain by Siluro-Devonian sedimentary and volcanic rocks of the Lanark Group. The latter is bounded to the south-east by the Pentland Fault, which brings it into contact 
with the Carboniferous rocks of the Midlothian Basin (Fig. 1). To the north-west, Carboniferous rocks of the Inverclyde Group rest unconformably on an eroded Siluro-Devonian land surface.

Beds of the North Esk Group strike NE to NNE. Mykura \& Smith (1962, p. 13) noted that, in general, beds in the North Esk Inlier young to the WNW, but that there were sections without good younging criteria in which the presence of local isoclinal folds could not be discounted. Robertson (1989) believed that the entire North Esk Group younged to the north-west. However, dish and pillar dewatering structures recorded in the Gutterford Burn [NT 1588 5904] in connection with this study indicate SE younging, suggesting that some local isoclinal folding is present.

The North Esk Group comprises five formations with a total thickness of at least 2500 metres (Fig. 5). Tipper (1976) divided the succession into the Reservoir, Deerhope, Wether Law Linn and Henshaw formations. Robertson (1989) subsequently redescribed these formations and added the Cock Rig Formation. Robertson's Lower, Middle and Upper members of the Wether Law Linn Formation are herein renamed the Grain Heads Siltstone Member (GHD), Lamb Rig Siltstone Member (LAR) and the Baddingsgill Mudstone Member (BDD). The group represents a regressive sequence from shallow marine (Reservoir, Deerhope, Cock Rig and Wether Law Linn formations) to terrestrial red-beds with minor marine incursions (Henshaw Formation). A complete sequence from the Reservoir Formation to the Henshaw Formation is present in the North Esk Inlier; only the Reservoir, Deerhope and Wether Law Linn formations are exposed in the Bavelaw Castle Inlier, and only the Reservoir Formation is present in the Loganlee Inlier (Barron 1998).

The Reservoir Formation, at the base of the succession, comprises at least $1100 \mathrm{~m}$ of mudstone and shale interbedded with siltstone and fine-grained sandstone. Its base is not exposed, but it is overlain by the Deerhope Formation comprising about $400 \mathrm{~m}$ of laminated and bioturbated siltstone, mudstone and shale. The latter formation contains a shelly fauna of rugose corals, brachiopods, bivalves, trilobites and pelmatozoans. The Cock Rig Formation consists of $100 \mathrm{~m}$ of medium- and coarse-grained, locally flaggy, cross-bedded sandstone, interbedded with clast-supported and poorly graded conglomerate. It is overlain by the silty mudstone, mudstone, siltstone and fine-grained sandstone of the Wether Law Linn Formation, which is about $250 \mathrm{~m}$ thick. At the top of the North Esk Group, the Wether Law Linn Formation is conformably overlain by the Henshaw Formation. This is at least $725 \mathrm{~m}$ thick and consists of red, medium- to coarse-grained sandstone and conglomerate with subordinate mudstone and siltstone.

The North Esk Group has yielded a variety of stratigraphically important fossils, including graptolites, brachiopods, conodonts, corals and trilobites. Rare graptolites occur in the Reservoir, Deerhope and Wether Law Linn formations, but are particularly common in the 
Gutterford Burn Limestone Beds, a series of lenticular calcareous siltstones within the Reservoir Formation (GBLB on Fig. 5). The graptolites indicate a late Telychian (late Llandovery) spiralis Biozone age for the Reservoir Formation, a mid spiralis Biozone to mid lapworthi Biozone age for the Deerhope Formation, and a probable latest Telychian lapworthi and/or insectus Biozone age for the Wether Law Linn Formation (Bull \& Loydell 1995; Loydell 2005). The Henshaw Formation is dated as early Wenlock on spore evidence (Wellman \& Richardson 1993), and the base of the Wenlock Series is placed at about the base of that formation or towards the top of the underlying Wether Law Linn Formation.

Depositional environments. Robertson (1989) considered the Reservoir, Deerhope and Cock Rig formations to comprise discrete lithofacies deposited in an offshore, deep-water, submarine fan complex, the Wether Law Linn Formation to be a shallow marine barrier complex, and the Henshaw Formation to be a terrestrial alluvial fan complex with minor marine incursions. However, Bull \& Loydell (1995) reinterpreted the depositional setting of the Reservoir Formation as a relatively shallow marine shelf, based on the graptolite association and the identification of sedimentary structures attributed to storm processes. They concluded that water depth was probably shallower than that implied by the offshore fan model. Clarkson \& Taylor (2002) considered the thinly graded mudstones and siltstones that comprise the bulk of the Deerhope Formation to be either interchannel overbank deposits of an inner submarine fan, as originally suggested by Robertson (1989), or distal storm beds. Influxes of more sandy material provided the substrate on which the coral faunas, that gave rise to the Deerhope Coral Beds and which characterise the formation, could thrive. Clarkson et al. (2001) interpreted the overlying Cock Rig Formation as the deposits of an offshore barrier system, with the flaggy mudstones and siltstones of the Deerhope Formation deposited from suspension flows below wave base on its seaward side. On the landward side of the Cock Rig offshore bar, Clarkson et al. (2001) suggested that the Wether Law Linn Formation was deposited in a broad marine lagoon, perhaps several kilometres across, in which fluctuating salinities with the occasional restoration of fully marine conditions culminated in brackish or freshwater conditions. The red sandstones of the Henshaw Formation record the onset of predominantly terrestrial sedimentation in the Wenlock, with some evidence for minor marine incursions.

\section{Palynology of the North Esk Group}


A total of 48 samples were collected from the North Esk, Bavelaw Castle and Loganlee Inliers (Fig. 5). Of these, 37 samples yielded palynomorphs. All formations were sampled except the Cock Rig Formation, which was considered unfavourable for organic microfossil preservation because of its red colour. Data used to compile Figs 6 and 7 are semi-quantitative, based on counts of specimens per slide made using standardised palynological preparation techniques. Acritarch taxonomy follows Mullins (2001).

\section{North Esk Inlier}

Palynological results from the North Esk Inlier are shown in Fig. 6. Acritarchs, chitinozoans and spores occur throughout the succession. The acritarchs generally form the most abundant component of the palynological assemblages, comprising more than $90 \%$ of the microfloras in each productive sample from the Reservoir Formation.

Reservoir Formation. Acritarch microfloras from the lower part of the Reservoir Formation, from the base of the measured section to approximately $275 \mathrm{~m}$ below the top of the formation, are of low diversity and abundance. Three of the twelve samples from this interval were barren (MPA 42011, 43849, 43848), and a further five samples yielded rare sphaeromorph acritarchs, either alone or accompanied by one or two other taxa that are equally rare (MPA 42010, 42008, 42012, 43851, 43842). The remaining four samples (MPA 42009, 43303, 43852, 43850) record the successive appearance of taxa that, for the most part, range through the rest of the Reservoir Formation and in some cases into higher formations.

The highest four samples (MPA 43843, 43296, 43847, 43846) from the formation show marked increases in abundance and diversity. These samples contain the most diverse acritarch microfloras in the sampled North Esk succession; chitinozoa and cryptospores are also consistently present, albeit in low numbers, in contrast to samples from lower in the succession. The increase in acritarch diversity in the higher part of the Reservoir Formation results from the first local appearances of a number of species, including Ammonidium microcladum, specimens of the Domasia trispinosa-elongata group, Tunisphaeridium tentaculaferum? and species of Eupoikilofusa, Veryhachium and Visbysphaera.

The acritarch microfloras from the highest four samples of the Reservoir Formation are dominated by sphaeromorph acritarchs, Moyeria cabottii and Tylotopalla spp., which together comprise between $26 \%$ and $74 \%$ of all acritarch specimens recorded from each sample. The species of Tylotopalla include forms with very short processes, like those of the Tylotopalla sp. 
of Priewalder (1987, pl. 14, figs 4-6), those with slightly longer processes as in T. deerlijkianum and T. astrifera (T. deerlijkianum - T. astrifera group), and forms with relatively long processes, comparable to T. tappaniae. Specimens assigned to the T. deerlijkianum - T. astrifera group are the most common. Sphaeromorph acritarchs, Moyeria cabotti and Tylotopalla spp. are also the dominant taxa in some samples from lower in the succession, although occurring in much lower numbers. For example, they comprise $40 \%, 30 \%$ and $26 \%$, respectively, of specimens recorded from MPA 43851, the only other specimen recorded from the sample being an undetermined acanthomorph acritarch. The common occurrence of sphaeromorph acritarchs, Moyeria cabottii and Tylotopalla spp. is thus a characteristic feature of samples from the Reservoir Formation, particularly those from the upper part of the formation. Diexallophasis denticulata, Schismatosphaeridium perforatum and Visbysphaera connexa are other prominent members of microfloras from the upper part of the Reservoir Formation, although these also occur lower in the succession.

The stratigraphical pattern of acritarch occurrences in the Reservoir Formation is thus one of a gradual upward increase in diversity and abundance, culminating in a marked increase in both in the upper part of the formation. First appearance datums (FADs) of some taxa in the Reservoir Formation are well above their first appearances elsewhere; Moyeria cabottii, for example, has been recorded from Middle to Upper Ordovician sections (Turner 1984; Vecoli \& Le Hérissé 2004; Molyneux et al. 2006). In other cases, such as that of Visbysphaera connexa, which has its first appearance in the spiralis Biozone of Gotland (Le Hérissé 1989), the local FAD of the species in the North Esk Inlier might be close to the base of its range elsewhere.

Deerhope Formation. There is a general decline in the abundance and diversity of acritarchs and chitinozoans above the Reservoir Formation, although both groups, together with rare cryptospores, are present in samples from the Deerhope and Wether Law Linn formations. Acritarch assemblages from the Deerhope Formation comprise species that range up from the Reservoir Formation, but abundance and diversity are much lower than in the upper part of the latter. Only one taxon, Buedingiisphaeridium?, has a first appearance in the Deerhope Formation, and this is represented by a single specimen in sample MPA 43304. In contrast, a number of species do not occur above the Reservoir Formation in the North Esk Inlier, including Schismatosphaeridium perforatum, Visbysphaera connexa and several species that appear in the diverse assemblages at the top of that formation (Ammonidium microcladum, Eupoikilofusa rochesterensis, E. striatifera, Tunisphaeridium tentaculaferum?, Veryhachium trispinosum, Visbysphaera gotlandica? and V. aff. oligofurcata). Moyeria cabottii, Tylotopalla spp. and sphaeromorph acritarchs are present in samples from the Deerhope Formation, but their records 
are impersistent. Furthermore, whereas Moyeria cabottii and sphaeromorph acritarchs may be relatively common where they do occur, the genus Tylotopalla is represented by single specimens in only three samples.

Wether Law Linn Formation. There is a slight recovery in acritarch abundance and diversity at the base of the Wether Law Linn Formation, accounted for in part by the first local appearances of taxa such as Leiofusa aff. tumida and Micrhystridium stellatum, and in part by the reappearance of taxa that occur in the Reservoir Formation but not in the Deerhope Formation, such as the Domasia trispinosa-elongata group and Visbysphaera dilatispinosa. Nevertheless, the abundance and diversity of assemblages from the Wether Law Linn Formation do not reach the levels seen at the top of the Reservoir Formation. Neither Moyeria nor Tylotopalla were recorded in samples from this formation in the North Esk Inlier, although rare specimens are present in the Wether Law Linn Formation of the Bavelaw Castle Inlier (see below). Samples from the top of the formation in the North Esk Inlier yielded sparse, low diversity assemblages, the highest sample yielding only sphaeromorph acritarchs and rare cryptospores (?Laevolancis divellomedia), suggesting marginal marine conditions prior to the onset of non-marine deposition of the Henshaw Formation.

Henshaw Formation. The Henshaw Formation yielded few marine microfossils, only rare sphaeromorph and acanthomorph acritarchs (Ammonidium? spp.), but more abundant and diverse spores and cyptospores than the underlying formations together with associated plant material. The productive samples are from exposures along the Lynslie Burn of the North Esk Inlier, close to the samples included in the study by Wellman \& Richardson (1993). The assemblages reported here are closely similar to those recorded by Wellman \& Richardson (1993). Neither Wellman \& Richardson (1993) nor this study recorded Moyeria cabottii this high in the North Esk succession, although Wellman \& Richardson (1993) recorded it as present in correlative strata in the Hagshaw Hills and Lesmahagow inliers. Both this study and that of Wellman \& Richardson (1993) recorded acritarchs in the Henshaw Formation (undetermined acanthomorph acritarchs in Wellman \& Richardson, 1993, text-fig. 4), whereas no marine forms were recorded from the Hagshaw Hills and Lesmahagow successions.

Bavelaw Castle and Loganlee inliers 
Five samples from the North Esk Group in the Bavelaw Castle Inlier and six from the Loganlee Inlier were analysed (Fig. 7). All are from the Reservoir Formation, except for the highest sample in the Bavelaw Castle Inlier, which is from the Wether Law Linn Formation.

The pattern of microfossil recovery from the Reservoir Formation of the Bavelaw Castle and Loganlee inliers is similar to the pattern seen in the North Esk Inlier. Samples from the Loganlee Inlier, which are across strike and down dip from the Bavelaw Castle samples and are therefore placed lower in the succession, were barren, except for the lowest sample, which yielded sparse sphaeromorph acritarchs, Multiplicisphaeridium sp. and cryptospore tetrads. In its sparsity, low diversity and composition, the assemblage from this sample resembles those from the lower part of the Reservoir Formation in the North Esk Inlier, although the preservation of palynomorphs in the Loganlee sample might also have been affected by intrusion of the Black Hill Felsite.

Nevertheless, the barren and sparse, low diversity assemblages from the Loganlee Inlier contrast with the more diverse and comparatively rich acritarch assemblages from the Reservoir Formation in the Bavelaw Castle Inlier. The latter are comparable to those from the upper part of the Reservoir Formation in the North Esk Inlier, although absolute abundances are lower. Nevertheless, Moyeria cabottii and specimens of the T. deerlijkianum - T. astrifera group are relatively abundant members of the Bavelaw Castle assemblages. Also present are Ammonidium microcladum and Tunisphaeridium tentaculaferum?, which are restricted to the upper part of the Reservoir Formation in the North Esk Inlier, and Schismatosphaeridium perforatum and Visbysphaera connexa, neither of which range above the Reservoir Formation there.

The reduction in acritarch diversity and abundance seen above the Reservoir Formation in the North Esk Inlier is also evident in the Bavelaw Castle Inlier, although there is only one sample from the higher part of the succession. Nevertheless, acritarch diversity and abundance in the sample from the Wether Law Linn Formation are lower than in the samples from the Reservoir Formation. In contrast to the samples from the North Esk Inlier, however, the single sample from the Wether Law Linn Formation in the Bavelaw Castle Inlier did yield specimens of Moyeria cabottii, and two questionable specimens of the T. deerlijkianum - T. astrifera group. 


\section{Silurian palynology of the Girvan Inlier: comparison with the North Esk Group}

One of the most striking aspects of the marine palynology of the North Esk Group is the predominance of sphaeromorph acritarchs, Moyeria cabottii and Tylotopalla spp. in samples from the Reservoir Formation, particularly, but not exclusively, in the more productive samples from the upper part of the formation. This association gives rise to assemblages with a distinctive character. Although late Llandovery acritarch assemblages from other Midland Valley inliers are poorly documented, there is evidence that similar sphaeromorph-MoyeriaTylotopalla-dominated acritarch microfloras occur at about the same level in the Silurian succession of the Girvan Inlier (Fig. 8). The records are from spot samples rather than systematically collected sections, so the stratigraphical range of the sphaeromorph-MoyeriaTylotopalla assemblage in the Girvan area is unknown. However, at least two of the known occurrences are from the Drumyork Flags Formation, a thick (c. $610 \mathrm{~m})$ unit of grey-green flaggy sandstone/mudstone turbidites (Cocks \& Toghill 1973) known to be of spiralis Biozone age (Floyd \& Williams 2003) and therefore a correlative of the Reservoir Formation.

One of the samples from the Drumyork Flags Formation (BGS sample number MPA 49700), from a tributary of the Buskin Burn [NS 3999 0512], 1180 m E of Largs, yielded abundant, wellpreserved acritarchs, accompanied by rarer cryptospores, chitinozoans and scolecodonts. Sphaeromorph acritarchs are the most common forms, but also common are specimens attributable to the Tylotopalla deerlijkianum-T. astrifera group. Other taxa recorded include the acritarchs Ammonidium microcladum, Ammonidium? sp., Cymatiosphaera sp., Diexallophasis denticulata, Dorsennidium europaeum, Lophosphaeridium sp., Micrhystridium spp., Moyeria cabottii and Visbysphaera spp., chitinozoans (Ancyrochitina, Conochitina?), scolecodonts and cryptospores including Laevolancis divellomedia and Tetrahedraletes medinensis. The second sample (MPA 49702), from a tributary south of Cawin Burn [NS 3714 0382], yielded an assemblage dominated by sphaeromorph acritarchs, Moyeria cabottii and Tylotopalla (T. deerlijkianum-T. astrifera group), accompanied by the acritarchs Diexallophasis denticulata, Domasia limaciformis?, Domasia trispinosa, Dorsennidium europaeum, Micrhystridium stellatum and Multiplicisphaeridium sp., and rare spores, including the cryptospores Laevolancis divellomedia and Tetrahedraletes medinensis and the miospore Ambitisporites?.

A third possible occurrence of the assemblage in the Girvan district is from a sample of greygreen sandstone and mudstone (MPA 50941), collected from Toddy Burn [NS 3196 0160], 425 $\mathrm{m}$ WSW of Cairn Hill. The sample yielded abundant acritarchs with rarer chitinozoans, scolecodonts and cryptospores. The microflora recorded from the sample includes common sphaeromorph acritarchs and specimens of the Tylotopalla deerlijkianum - T. astrifera group, 
accompanied by acanthomorph acritarchs, Ammonidium microcladum, Diexallophasis denticulata, Domasia trispinosa, Dorsennidium europaeum, Eupoikilofusa striatifera?, Helosphaeridium?, Micrhystridium stellatum, Multiplicisphaeridium sp., Salopidium granuliferum, Schismatosphaeridium perforatum, Veryhachium trispinosum, Veryhachium sp., Visbysphaera connexa and Visbysphaera sp., chitinozoans including Ancyrochitina sp., scolecodonts, and the cryptospores Laevolancis divellomedia and Tetrahedraletes medinensis. Despite the absence of Moyeria, the assemblage bears a strong resemblance to those from the Drumyork Flags Formation and the upper part of the Reservoir Formation.

Overlying formations in the Girvan Inlier have also yielded marine microfloral assemblages, indicating the persistence of marine conditions into the Wenlock, in contrast to the situation in the North Esk Inlier. The microfloras recorded by Dorning (1982) from the Knockgardner Sandstone Formation are diverse and contain a number of species recorded from the sphaeromorph-Moyeria-Tylotopalla assemblage, including Ammonidium microcladum, Domasia trisipinosa and Schismatosphaeridium perforatum, but neither Moyeria cabottii nor species of Tylotopalla were recorded (Fig. 8).

A more restricted assemblage, dominated by sphaeromorph acritarchs with rare Diexallophasis denticulata, Micrhystridium, scolecodonts and the cryptospore Tetrahedraletes medinensis, was recorded from the overlying Straiton Grits Formation, from a burn [NS 3697 0459] $920 \mathrm{~m}$ WNW of Bennan Straiton. The assemblage suggests a marginal marine environment, consistent with the record of a sparse and restricted fauna of beyrichiacean ostracods and bivalves from the Straiton Grits Formation, which also suggests very shallow marine or brackish water, possibly lagoonal conditions (Floyd \& Williams 2003), and in contrast to the approximately contemporaneous, largely non-marine Henshaw Formation of the North Esk Inlier. A similar assemblage, also dominated by sphaeromorph acritarchs in a low diversity microflora with Diexallophasis denticulata, Lophosphaeridium and Veryhachium trispinosum, was recorded by Dorning (1982) from the Straiton Grits Formation exposed in a quarry to the south-west [NS 3445 0362].

\section{Discussion}

The palynological assemblages from the Reservoir, Deerhope and Wether Law Linn formations are consistent with the late Llandovery age indicated by graptolite evidence for these formations. Clarkson et al. (2001, p. 481) noted that unpublished acritarch evidence suggested that the Aeronian-Telychian boundary might lie close to the base of the Deerhope Formation, but none of 
the taxa recorded here from the Reservoir Formation are diagnostic of the Aeronian, and all would be consistent with a late Llandovery age. Most of the species recorded range from the Llandovery into the Wenlock, some having long ranges above and below the boundary, but any definite Wenlock indicators are absent. Of particular interest are the species of Visbysphaera, especially V. connexa, V. dilatispinosa and V. erratica brevis. Visbysphaera connexa and V. erratica brevis have their first appearances in the spiralis Biozone of Gotland (Le Hérissé 1989), and V. dilatispinosa has its first appearance in the upper Telychian of Norway (Smelror 1987) and Gotland (Le Hérissé 1989, recorded as V. pirifera). All three species range into the Wenlock, V. connexa having its last appearance in the lower part of the Högklint Formation on Gotland (lower part of the Sheinwoodian Stage), and the other two species ranging into the Homerian. The last appearance of Tylotopalla deerlijkianum is close to the Llandovery-Wenlock boundary on Gotland (Le Hérissé 1989).

The distinctive sphaeromorph-Moyeria-Tylotopalla acritarch assemblage is of particular interest because of its potential for correlating Silurian successions in the Midland Valley, given that it is shown here to occur in the spiralis Biozone of both the North Esk and Girvan inliers. However, using the assemblage for correlation depends on demonstrating that it has a restricted stratigraphical distribution, for example by systematic investigation of the Girvan Silurian succession, which extends down to the upper Rhuddanian, and by examining late Llandovery successions in other Midland Valley inliers for comparable assemblages. In this context, it is worth reiterating that the younger (Wenlock) assemblage recorded by Dorning (1982) from the Knockgardner Sandstone Formation of the Girvan succession does not appear to be the sphaeromorph-Moyeria-Tylotopalla assemblage.

It is almost certain that the predominance of sphaeromorph acritarchs and Moyeria in the assemblage is due to environmental factors. Sphaeromorph-dominated assemblages are generally considered to be characteristic of either nearshore or deep basinal marine environments, at the opposite ends of the environmental spectrum along an onshore-offshore gradient, presumed to reflect their tolerance of varying ecological conditions (Molyneux et al. 1996). In addition, Moyeria cabottii was noted by Gray \& Boucot (1989) to be abundant in nonmarine and nearshore marine deposits, and Wellman \& Richardson (1993) recorded it from nonmarine successions of Wenlock age in the Hagshaw Hills and Lesmahagow inliers, concluding that it was probably derived from an organism that inhabited continental water bodies. On this basis, the predominance of both sphaeromorph acritarchs and $M$. cabottii in the Reservoir Formation might suggest a nearshore marine origin for at least some components of the assemblage, although the diversity of the assemblages from the top of the formation is more consistent with an offshore shelf environment. Interpretations of the depositional environment of 
the Reservoir Formation include Robertson's (1989) deep-water, turbiditic, submarine fan model and Bull \& Loydell's (1995) suggestion of a shallow-water shelf environment down to maximum storm wave base; Clarkson et al. (1998) also indicated a mid to outer shelf setting for the Drumyork Flags Formation. The palynological data do not provide critical evidence to distinguish between deep-water fan and shelf environments since palynomorphs can be redistributed in turbidite systems, but the pattern of palynomorph occurrence through the formation, with the gradual incoming of species through the succession and the marked increase in abundance and diversity in the upper part of the formation all suggest some kind of environmental change. The composite log of the North Esk section (Fig. 5) shows an upward increase in the proportion of siltstone and fine sandstone beds in the succession, coincident with the increase in acritarch abundance and diversity, which might indicate closer proximity to the source and/or upward shallowing.

Questions that remain unanswered are why there should be such an influx of taxa in the upper part of Reservoir Formation compared with the lower part of the formation, and whether this pattern is repeated in other sections. The influx of taxa is considered to be an environmental response rather than a preservational effect as there is no apparent difference in preservation between acritarchs from the lower and upper parts of the formation. One possibility is that acritarch microfloras track changes in the location of certain physical and chemical properties of water-masses, for example nutrient availability, salinity, temperature, through time, in a manner analogous to the way in which graptolite faunas track changes in the location of their preferred position on continental margins (Finney \& Berry 1997, 1999; Goldman et al. 1999). If so, the influx of acritarch taxa may be signalling physical and/or chemical changes in the environment during deposition of the upper part of the Reservoir Formation, either at the site of deposition if they are in situ, or at their source if they have been resedimented. More work on quantitative changes in acritarch assemblages through time is needed to test this proposition.

\section{Acknowledgements}

We thank Chris Thomas and Maxine Akhurst for their comments on an earlier draft of this paper, and Sarah Arkley for providing comparative samples from the Girvan succession. This paper is published by permission of the Executive Director, British Geological Survey (NERC). 


\section{References}

BARRON, H. F. 1998. Geology of the central Pentland Hills. British Geological Survey Technical Report WA/98/41. 34pp.

BULL, E. E. \& LOYDELL, D. K. 1995. Upper Telychian graptolites from the North Esk Inlier, Pentland Hills, near Edinburgh. Scottish Journal of Geology 31, 163-170.

BURGESS, N. D. 1991. Silurian cryptospores and miospores from the type Llandovery area, South-west Wales. Palaeontology 34, 575-599.

BURGESS, N. D. \& RICHARDSON, J. B. 1991. Silurian cryptospores and miospores from the type Wenlock area, Shropshire, England. Palaeontology 34, 601-628.

CAMERON, I. B. \& STEPHENSON, D. 1985. The Midland Valley of Scotland. British Regional Geology, No. 5. H.M.S.O., London.

CLARKSON, E. N. K., HARPER, D. A. T. \& HÖEY, A. N. 1998. Basal Wenlock biofacies from the Girvan district, SW Scotland. Scottish Journal of Geology 34, 61-71.

ClARKSON, E. N. K., HARPER, D. A. T. \& TAYLOR, C. M. 2001. Scottish Silurian Shorelines. Transactions of the Royal Society of Edinburgh: Earth Sciences 91, 479-487.

CLARKSON, E. N. K. \& TAYLOR, C. M. 2002. The Deerhope Formation in the North Esk Inlier, Pentland Hills, Scotland. Special Papers in Palaeontology 67, 29-44.

COCKS, L. R. M. \& TOGHILL, P. 1973. Biostratigraphy of the Silurian rocks of the Girvan district. Journal of the Geological Society, London, 129 209-243.

CRAMER, F. H. 1970. Distribution of selected Silurian acritarchs; an account of the palynostratigraphy and paleogeography of selected Silurian acritarch taxa. Revista Española de Micropaleontología, número extraordinario, 1-203, pls I-XXIII.

CRAMER, F. H., \& DÍEZ DE CRAMER, M. DEL C. R. 1972. North American Silurian palynofacies and their spatial arrangement: acritarchs. Palaeontographica Abteilung B 138, 107-180, pls 31-36.

DEFLANDRE, G. 1945. Microfossiles des calcaires siluriens de la Montagne Noire. Annales de paléontologie 31, 41-75.

DORNING, K. J. 1981. Silurian acritarchs from the type Wenlock and Ludlow of Shropshire, England. Review of Palaeobotany and Palynology 34, 175-203.

DORNING, K. J. 1982. Early Wenlock acritarchs from the Knockgardner and Straiton Grit Formations of Knockgardner, Ayrshire. Scottish Journal of Geology 18, 267-273.

DOWNIE, C. 1959. Hystrichospheres from the Silurian Wenlock shale of England. Palaeontology 2, 56-71. 
DOWNIE, C. 1960. Deunffia and Domasia, new genera of hystrichospheres. Micropaleontology 6, 197-202.

DOWNIE, C. 1963. 'Hystrichospheres' (acritarchs) and spores of the Wenlock Shales (Silurian) of Wenlock, England. Palaeontology 6, 625-652.

EISENACK, A., CRAMER, F. H. \& DÍEZ, M. DEL C. R. 1976. Katalog der fossilen Dinoflagellaten, Hystrichosphären und verwandten Mikrofossilien. Band IV Acritarcha 2. Teil. E. Schweizerbart'sche Verlagsbuchhandlung, Stuttgart.

FINNEY, S. C. \& BERRY, W. B. N. 1997. New perspectives on graptolite distributions and their use as indicators of platform margin dynamics. Geology 25, 919-922.

FINNEY, S. C. \& BERRY, W. B. N. 1999. Late Ordovician graptolite extinction: the record from continental margin sections in central Nevada, USA. Acta Universitatis Carolinae Geologica 43, 195-198.

FLOYD, J. D. \& WILLIAMS, M. 2003. A revised correlation of Silurian rocks in the Girvan district, SW Scotland. Transactions of the Royal Society of Edinburgh: Earth Sciences 93, 383-392.

GOLDMAN, D., MITCHELL, C. E. \& JOY, M. P. 1999. The stratigraphic distribution of graptolites in the classic upper Middle Ordovician Utica Shale of New York State: an evolutionary succession or a response to relative sea-level change? Paleobiology 25, 273294.

GRAY, J. \& BOUCOT, A. J. 1989. Is Moyeria a euglenoid? Lethaia 22, 447-456.

HOFFMEISTER, W. S. 1959. Lower Silurian plant spores from Libya. Micropaleontology 5, 331-334.

KIRYANOV, V. V. 1978. Akritarkhi siluria Volyno-Podolii. Akademiya Nauk Ukrainskoi SSR, Institut Geologicheskikh Nauk, Kiev, Naukova Dumka, 116 pp., pls 1-20.

LAUFELD, S. 1974. Silurian chitinozoa from Gotland. Fossils and Strata No. 5, 1-130.

LE HÉRISSÉ, A. 1989. Acritarches et kystes d'algues Prasinophycées du Silurien de Gotland, Suède. Paleontographia Italica 76, 57-302.

LISTER, T. R. 1970. The acritarchs and chitinozoa from the Wenlock and Ludlow series of the Ludlow and Millichope areas, Shropshire. Monograph of the Palaeontographical Society, London, 1-100, pls 1-13. (Publ. No. 528, part of Vol. 124 for 1970).

LOEBLICH, A. R. Jr. 1970. Morphology, ultrastructure and distribution of Paleozoic acritarchs. Proceedings of the North American Paleontological Convention, Chicago, 1969, part G, 2, 705-788, pls 1-38.

LOYDELL, D. K. 2005. Graptolites from the Deerhope Formation, North Esk Inlier. Scottish Journal of Geology, 41, 189-190. 
MARTIN, F. 1978. Sur quelques Acritarches llandovériens de Cellon (Alpes Carniques Centrales, Autriche). Verhandlungen der Geologischen Bundesanstalt Wien 1978 (2), 3542.

MCKERROW, W. S., DEWEY, J. F. \& SCOTESE, C. R. 1991. The Ordovician and Silurian development of the Iapetus Ocean. In BASSETT, M. G., LANE, P. D. \& EDWARDS, D. (eds) The Murchison Symposium; proceedings of an international conference on the Silurian System. Special Papers in Palaeontology 44, 165-178.

MILLER, M. A. \& EAMES, L. R. 1982. Palynomorphs from the Silurian Medina Group (lower Llandovery) of the Niagara Gorge, Lewiston, New York, U.S.A. Palynology, 6, 221-254.

MOLYNEUX, S. G., LE HÉRISSÉ, A. \& WICANDER, R. 1996. Chapter 16. Palaeozoic phytoplankton. In JANSONIUS, J. \& MCGREGOR, D. C. (eds) Palynology: principles and applications. American Association of Stratigraphic Palynologists Foundation 2, 493-529.

MOLYNEUX, S. G., OSTERLOFF, P., PENNEY, R. \& SPAAK, P. 2006. Biostratigraphy of the Lower Palaeozoic Haima Supergroup, Oman; its application in sequence stratigraphy and hydrocarbon exploration. GeoArabia 11, 17-48.

MULLINS, G. L. 2001. Acritarchs and prasinophyte algae of the Elton Group, Ludlow Series, of the type area. Monograph of the Palaeontographical Society, London, 1-154, pls 1-18. (Publ. No. 616, part of Vol. 155 for 2001).

MYKURA, W. \& SMITH, J. D. D. 1962. Ordovician and Silurian. In MITCHELL, G. H. \& MYKURA, W. (eds) The geology of the neighbourhood of Edinburgh. Memoir of the Geological Survey, Scotland (3rd edition), 10-22.

PHILliPS, E. R., BARRON, H. F., SMITH, R. A. \& ARKLEY, S. 2004. Composition and provenance of the Silurian to Devonian sandstone sequences of the southern Midland Valley. Scottish Journal of Geology 40, 23-42.

PHILLIPS, E. R., SMITH, R. A. \& CARROLL, S. 1998. Strike-slip, terrane accretion and the preCarboniferous evolution of the Midland Valley of Scotland. Transactions of the Royal Society of Edinburgh: Earth Sciences 89, 209-224.

PLAYFORD, G. 1977. Lower to Middle Devonian acritarchs from the Moose River Basin, Ontario. Geological Survey of Canada, Bulletin 279, 1-87, pls 1-20.

PRIEWALDER, H. 1987. Acritarchen aus dem Silur des Cellon-Profils, Karnische Alpen, Österreich. Abhandlungen der Geologischen Bundesanstalt 40, 1-121.

RICHARDSON, J. B. \& IOANNIDES, N. S. 1973. Silurian palynomorphs from the Tanezzuft and Acacus Formations, Tripolitania, North Africa. Micropaleontology 19, 257-307. 
ROBERTSON, G. 1989. A palaeoenvironmental interpretation of the Silurian rocks in the Pentland Hills, near Edinburgh, Scotland. Transactions of the Royal Society of Edinburgh: Earth Sciences 80, 127-141.

ROLFE, W. D. I. 1960. The Silurian Inlier of Carmichael, Lanarkshire. Transactions of the Royal Society of Edinburgh 64, 245-260.

ROLFE, W. D. I. 1961. The geology of the Hagshaw Hills Silurian inlier, Lanarkshire. Transactions of the Edinburgh Geological Society 18, 240-269.

SARJEANT, W. A. S. \& STANCLIFFE, R. P. W. 1994. The Micrhystridium and Veryhachium complexes (Acritarcha: Acanthomorphitae and Polygonomorphitae): a taxonomic reconsideration. Micropaleontology 40, 1-77.

SMELROR, M. 1987. Early Silurian acritarchs and prasinophycean algae from the Ringerike District, Oslo Region (Norway). Review of Palaeobotany and Palynology 52, 137-159.

SMITH, R. A. 1995. The Siluro-Devonian evolution of the southern Midland Valley of Scotland. Geological Magazine 132, 503-513.

STAPLIN, F. L., JANSONIUS, J. \& POCOCK, S. A. J. 1965. Evaluation of some acritarchous hystrichosphere genera. Neues Jahrbuch für Geologie und Paläontologie, Abhandlungen 123, $167-201$.

STROTHER, P. K. \& TRAVERSE, A. 1979. Plant microfossils from Llandoverian and Wenlockian rocks of Pennsylvania. Palynology 3, 1-21.

STOCKMANS, F. \& WILLIÈRE, Y. 1962. Hystrichosphères du Dévonien belge (Sondage de l'Asile d'aliénés à Tournai). Bulletin de la Société belge de géologie, de paléontologie et d'hydrologie 71, 41-77.

TIPPER, J. C. 1976. The stratigraphy of the North Esk Inlier. Scottish Journal of Geology 12, 1522.

TURNER, R. E. 1984. Acritarchs from the type area of the Ordovician Caradoc Series, Shropshire, England. Palaeontographica Abteilung B 190, 87-157, pls 1-15.

VANDENBROUCKE, T., VERNIERS, J. \& CLARKSON, E. N. K. 2003. A chitinozoan biostratigraphy of the Upper Ordovician and lower Silurian strata of the Girvan area, Midland Valley, Scotland. Transactions of the Royal Society of Edinburgh: Earth Sciences 93, 111-134. VECOLI, M. \& LE HÉRISSÉ, A. 2004. Biostratigraphy, taxonomic diversity and patterns of morphological evolution of Ordovician acritarchs (organic-walled microphytoplankton) from the northern Gondwana margin in relation to palaeoclimatic and palaeogeographic changes. Earth-Science Reviews 67, 267-311.

WELLMAN, C. H. 1995. "Phytodebris" from Scottish Silurian and Lower Devonian continental deposits. Review of Palaeobotany and Palynology 84, 255-279. 
WELLMAN, C. H. \& RICHARDSON, J. B. 1993. Terrestrial plant microfossils from Silurian inliers of the Midland Valley of Scotland. Palaeontology 36, 155-193.

WILLIAMS, D. M. \& HARPER, D. A. T. 1988. A basin model for the Silurian of the Midland Valley of Scotland and Ireland. Journal of the Geological Society, London 145, 741-748. 


\section{Figure Captions:}

Fig. 1. Location of Midland Valley Silurian inliers and simplified solid geological map of the Pentland Hills.

Fig. 2. Generalised vertical sections of Silurian successions in Midland Valley inliers (after Wellman \& Richardson 1993, text-fig. 2).

Fig. 3. Geological map of the North Esk Inlier, Pentland Hills.

Fig. 4. Geological map of the Bavelaw Castle and Loganlee inliers, Pentland Hills.

Fig. 5 Generalised vertical sections and sample points for the Silurian successions in the North Esk, Bavelaw Castle and Loganlee inliers, Pentland Hills. FB: Lyne Water Fish Bed; QC: Quartzite Conglomerate; IC: Igneous Conglomerate; DCB: Deerhope Coral Bed; SB: starfish bed; GBLB: Gutterford Burn Limestone Beds.

Fig. 6. Stratigraphical occurrence of acritarchs, chitinozoans, spores and miscellaneous palynomorphs in the Silurian succession of the North Esk Inlier. The shaded band running across the figure at the level of the upper Reservoir Formation signifies acritarch assemblages of high diversity and abundance dominated by sphaeromorph acritarchs, Moyeria cabottii and Tylotopalla spp.

Fig. 7. Stratigraphical occurrence of acritarchs, chitinozoans, spores and miscellaneous palynomorphs in the Silurian successions of the Loganlee and Bavelaw Castle inliers.

Fig. 8. Comparison of late Llandovery-Wenlock palynological assemblages from the Pentland Hills and Girvan. The symbols '(x)' and '(?)' in the Drumyork Flags Formation column are definite and tentative identifications, respectively, of taxa that are probably from the Drumyork Flags; taxa indicated by symbols without brackets are definitely from the Drumyork Flags. Data for the Henshaw Formation are from Wellman \& Richardson (1993) and this paper; data for the Knockgardner Sandstone Formation are from Dorning (1982); data for the Straiton Grits Formation are from Dorning (1982) and this paper. 
Fig. 9. Acritarchs of the sphaeromorph-Moyeria cabottii-Tylotopalla spp. assemblage in the upper Llandovery of the North Esk Inlier (Reservoir Formation) and Girvan Inlier (Drumyork Flags Formation). The bar in (5) is $10 \mu \mathrm{m}$; the same magnification applies to all figures. Specimens are stored in the MPK collection (type and figured microfossils and palynomorphs) of the British Geological Survey at Keyworth. MPA numbers are registered sample numbers (see Figs 3-7 for locations and stratigraphy).

(1) Moyeria cabottii (Cramer) Miller \& Eames 1982. MPK 13381. MPA 43846, slide 1, England Finder co-ordinate S50/0. Reservoir Formation, North Esk Inlier.

(2) Moyeria cabottii (Cramer) Miller \& Eames 1982. MPK 13382. MPA 43846, slide 2, R46/0. Reservoir Formation, North Esk Inlier.

(3) Moyeria cabottii (Cramer) Miller \& Eames 1982. MPK 13384. MPA 43846, slide 1, G49/0. Reservoir Formation, North Esk Inlier.

(4) Schismatosphaeridium perforatum Staplin, Jansonius \& Pocock 1965. MPK 13383. MPA 43846, slide 1, K69/2. Reservoir Formation, North Esk Inlier.

(5) Dorsennidium europaeum (Stockmans \& Willière) Sarjeant \& Stancliffe 1994. MPK 13386. MPA 43846, slide 1, L49/2. Reservoir Formation, North Esk Inlier.

(6) Domasia trispinosa-elongata grp. MPK 13385. MPA 43843, slide 1, S45/2. Reservoir Formation, North Esk Inlier.

(7) Domasia trispinosa-elongata grp. MPK 13390. MPA 43843, slide 1, H67/3. Reservoir Formation, North Esk Inlier.

(8) Large, thick-walled sphaeromorph acritarch. MPK 13387. MPA 49700, slide 1, K44/2. Drumyork Flags Formation, Girvan Inlier.

(9) Visbysphaera aff. connexa Le Hérissé 1989. MPK 13393. MPA 43846, slide 1, X71/2. Reservoir Formation, North Esk Inlier.

(10, 11) Visbysphaera aff. connexa Le Hérissé 1989. MPK 13394. MPA 43846, slide 2, J57/2. Reservoir Formation, North Esk Inlier. 
Fig. 10. Acritarchs of the sphaeromorph-Moyeria cabottii-Tylotopalla spp. assemblage in the upper Llandovery of the North Esk Inlier (Reservoir Formation) and Girvan Inlier (Drumyork Flags Formation). The bar in (4) is $10 \mu \mathrm{m}$; the same magnification applies to all figures. Specimens are stored in the MPK collection (type and figured microfossils and palynomorphs) of the British Geological Survey at Keyworth. MPA numbers are registered sample numbers (see Figs 3-7 for locations and stratigraphy).

(1-3) Tylotopalla deerlijkianum-astrifera grp. MPK 13392. MPA 49700, slide 1, England Finder co-ordinate K54/0. Drumyork Flags Formation, Girvan Inlier.

(4, 5) Tylotopalla deerlijkianum-astrifera grp. MPK 13389. MPA 43846, slide 2, M57/1. Reservoir Formation, North Esk Inlier.

(6, 7) Tylotopalla deerlijkianum-astrifera grp. MPK 13388. MPA 43846, slide 2, V70/3. Reservoir Formation, North Esk Inlier.

(8) Tylotopalla deerlijkianum-astrifera grp. MPK 13391. MPA 43846, slide 2, R71/1. Reservoir Formation, North Esk Inlier. 
(Main Inlier)

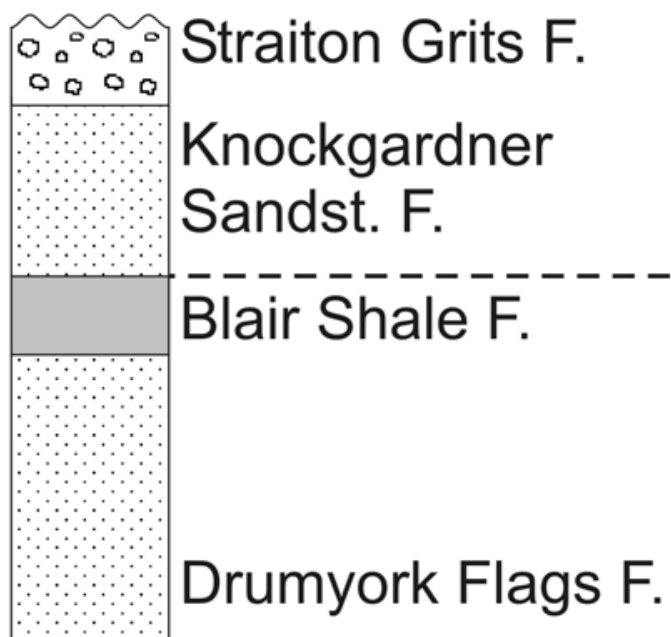

Lauchlan Mudst. F. Protovirgularia Grits F.

Penkill Mudst. F.

1. 2.

Pencleuch Shale F.

Saugh Hill Grits F.

Tralorg Shale F.
Plewland

Sandst. F.

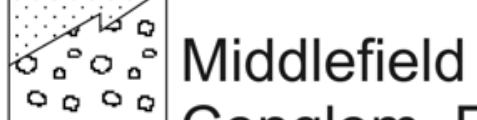

$\begin{array}{ccc}0.0 & 0 \\ 0 & 0 & 0\end{array}$

000

Logan F.

Slot.Burn F.

Monument $F$.

Dippal Burn. F.

Birkenhead

Sandst. F.

से

$\beta$ से Leaze F.

Dunside $F$.

Blaeberry $F$.

Kip Burn F.

Castle F.

$\beta \beta$ $\beta$ Q Quarry Arer

Greywacke

O.

0.0. Hareshaw

0000 Coniglom. F

Gully Redbe

Fish Bed F.

Douglas Water ,

0000 Parishholm Cor

Ree Burn F.

Smithy Burr Siltstone F.

Patrick Burn F.

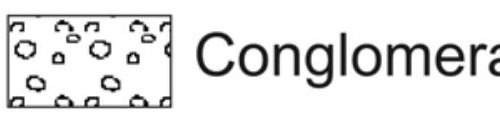

Sandstone

Ponesk Burn F.
Siltstone 


\section{Fault}

- sample locality

43842 - productive palynological sample 43849 - barren palynological sample

(All sample numbers bear the prefix 'MPA')

659

658

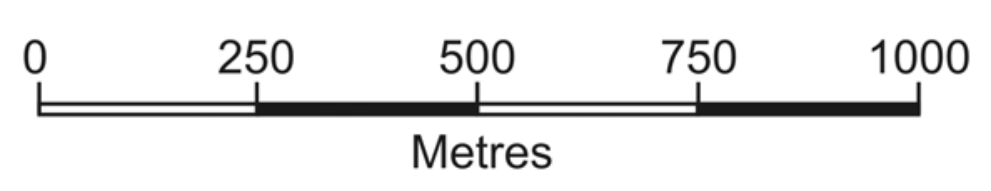

Little

Hill

\section{Lamb Rig}

Grain

Heads

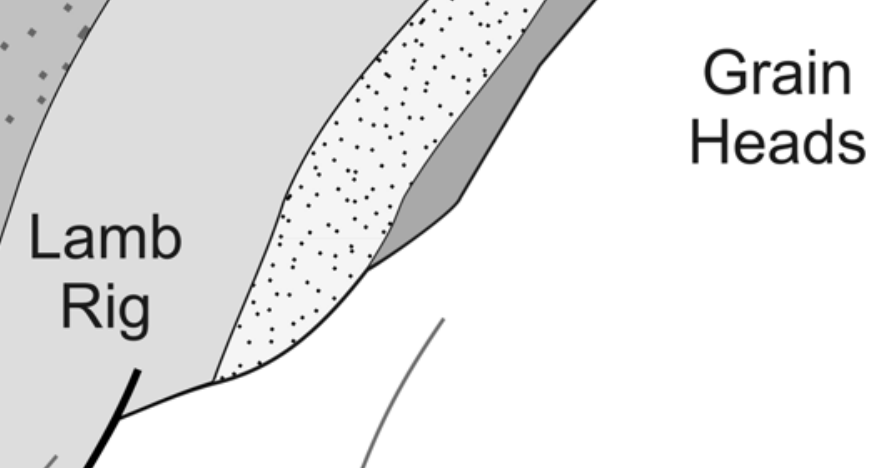


Fault

- sample locality

MPA 42007 - productive palynological sample 64 MPA 42002 - barren palynological sample

Threipmuir Reservoir
Bavelaw Castle 6

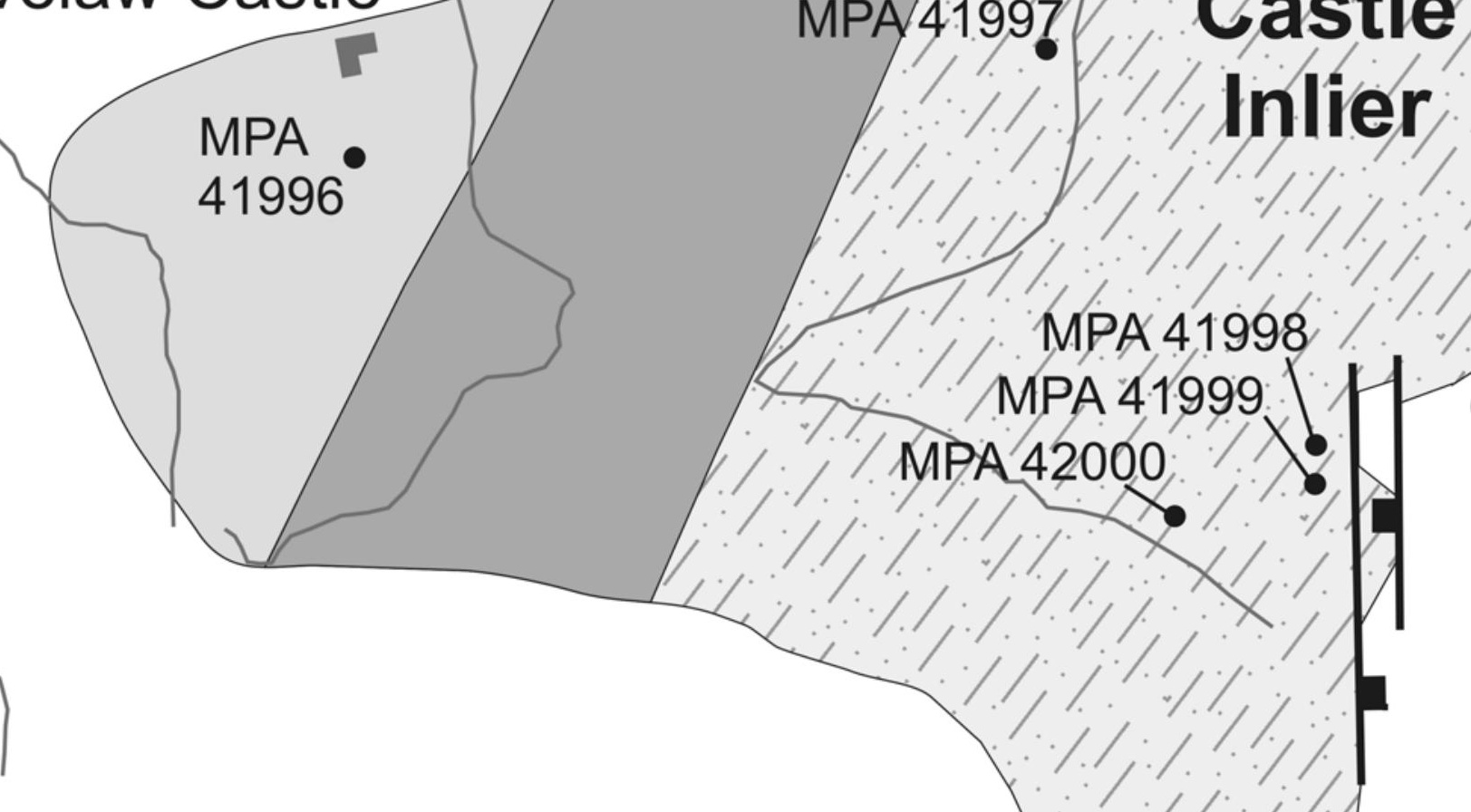

Bavelav Castle Inlier Metres

MPA 41998 MPA 41999 MPA 190 


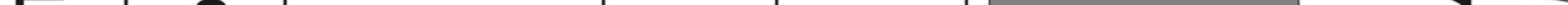




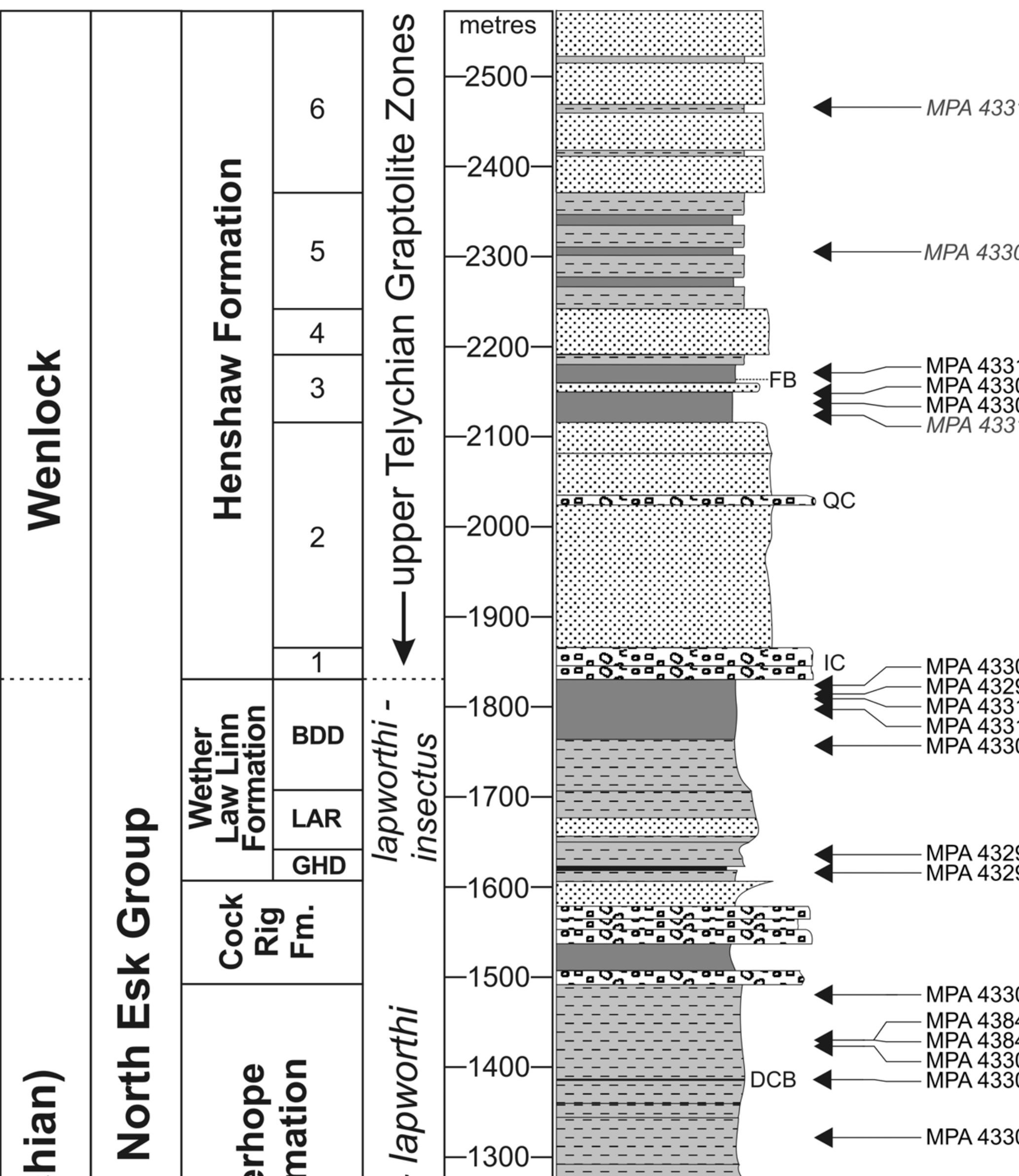




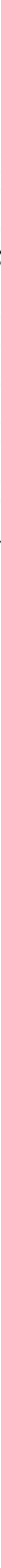




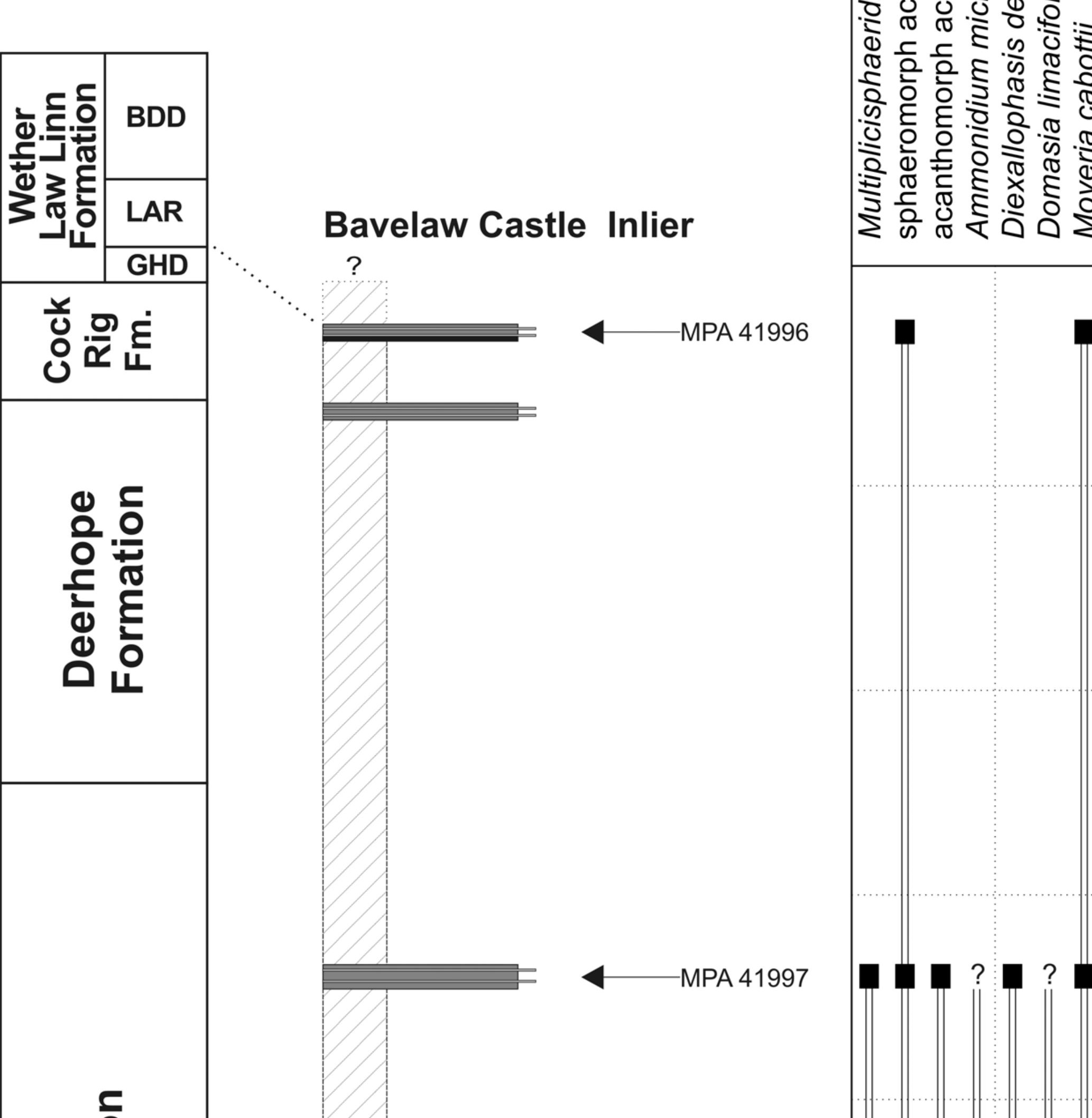



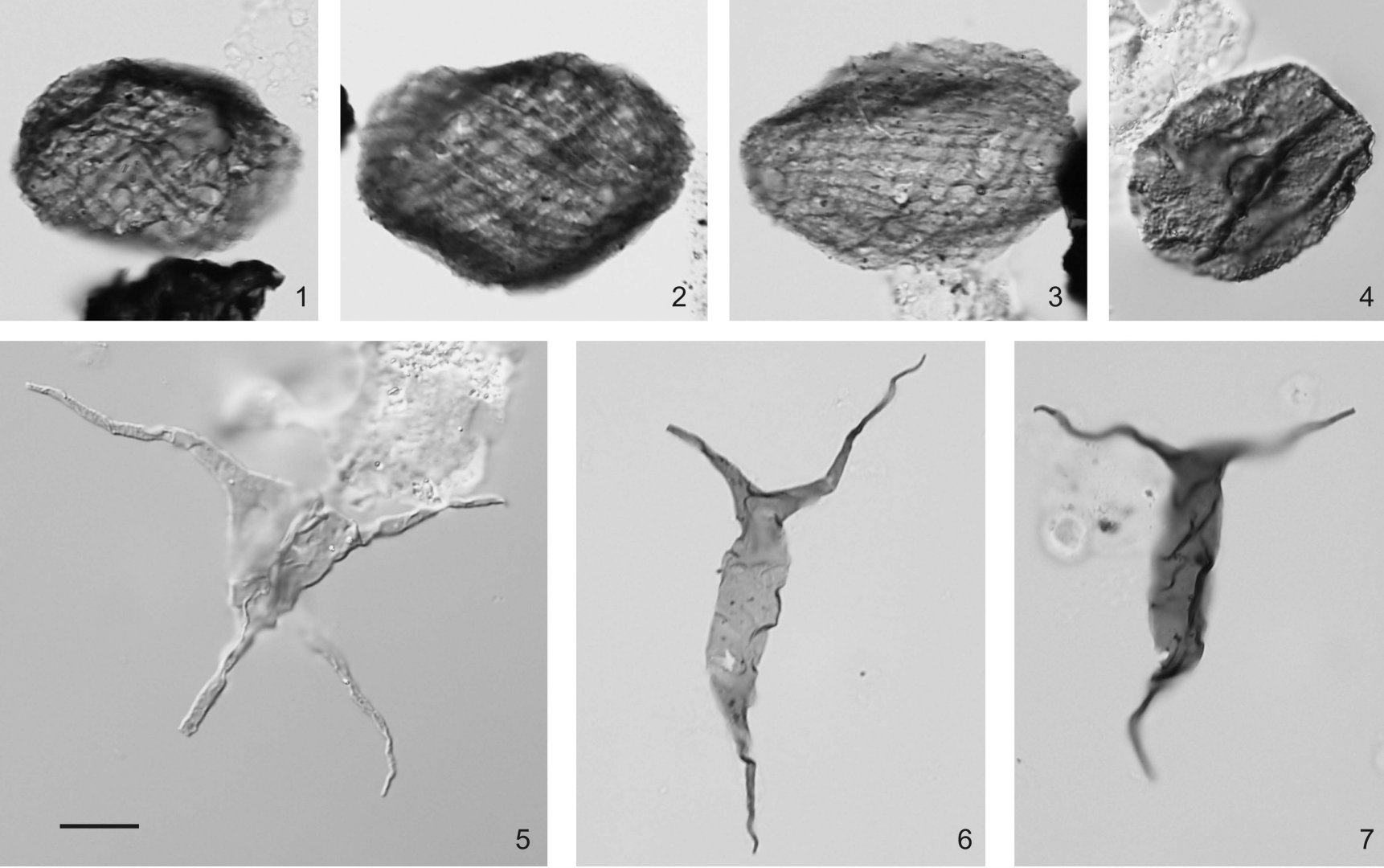

6

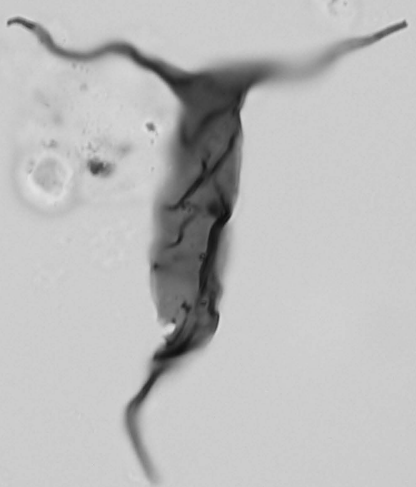

7
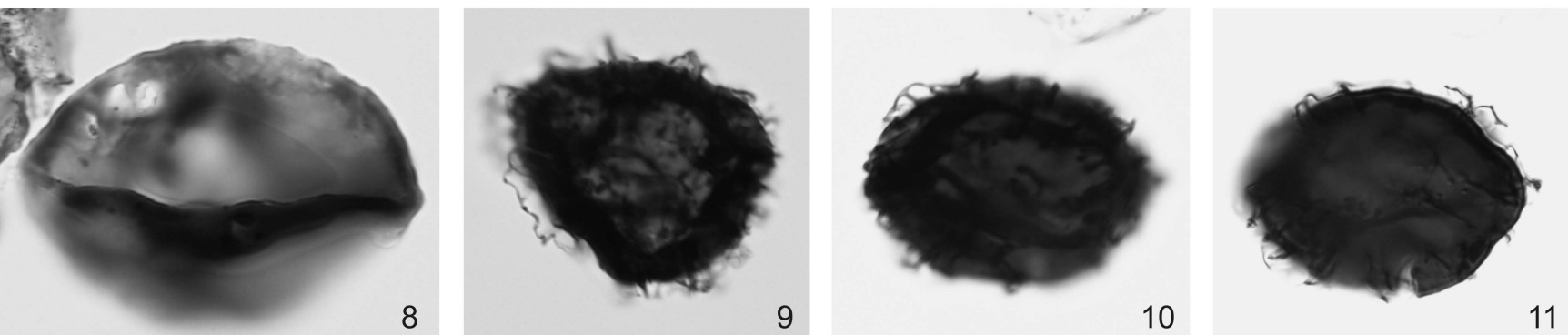

11 


\begin{tabular}{|c|c|c|c|c|c|c|c|c|c|}
\hline \multirow{2}{*}{\multicolumn{2}{|c|}{\begin{tabular}{|l} 
Chronostratigraphy \\
Graptolite Zone
\end{tabular}}} & \multicolumn{5}{|c|}{ Upper Llandovery } & \multirow{2}{*}{\multicolumn{3}{|c|}{ Wenlock }} \\
\hline & & \multicolumn{2}{|c|}{ spiralis } & \multirow{2}{*}{$\begin{array}{c}\text { mid spiralis - } \\
\text { mid lapworthi } \\
\end{array}$} & \multicolumn{2}{|c|}{ lapworthi-insectus } & & & \\
\hline & & 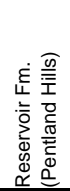 & 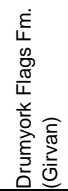 & & 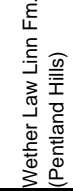 & 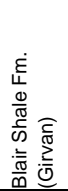 & 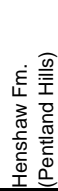 & 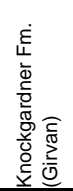 & 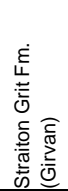 \\
\hline \multirow{51}{*}{$\begin{array}{l}\frac{0}{0} \\
\frac{0}{0} \\
\frac{5}{5} \\
\frac{0}{4}\end{array}$} & acanthomorph acritarchs & $\mathrm{x}$ & $(\mathrm{x})$ & & $\mathrm{x}$ & \multirow{70}{*}{$\begin{array}{l}\frac{\pi}{\pi} \\
\frac{\pi}{0} \\
\stackrel{0}{\complement}\end{array}$} & $\mathrm{x}$ & & \\
\hline & Ammonidium microcladum (Downie) Lister 1970 & $\mathrm{x}$ & $\mathrm{x}$ & & & & & $\mathrm{x}$ & \\
\hline & Ammonidium spp. & $\mathrm{x}$ & ? & $\mathrm{x}$ & & & ? & $\mathrm{x}$ & \\
\hline & Buedingiisphaeridium? spp. & & & $\mathrm{x}$ & & & & & \\
\hline & Cymatiosphaera heloderma Cramer \& Díez 1972 & $\mathrm{x}$ & & & ? & & & & \\
\hline & Cymatiosphaera octoplana Downie 1959 & & & & & & & $\mathrm{x}$ & \\
\hline & Cymatiosphaera? sp. (large, spongy wall) & $\mathrm{x}$ & & & & & & & \\
\hline & Cymatiosphaera spp. & $\mathrm{x}$ & $\mathrm{x}$ & $\mathrm{x}$ & & & & & \\
\hline & $\begin{array}{l}\text { Diexallophasis denticulata (Stockmans \& Willière) Loeblich } 1970 \\
\text { [D. remota (Deunff) Playford } 1977 \text { group] }\end{array}$ & $\mathrm{x}$ & $\mathrm{x}$ & $\mathrm{x}$ & $\mathrm{x}$ & & & $\mathrm{x}$ & $\mathrm{x}$ \\
\hline & Domasia limaciformis (Stockmans \& Willière) Cramer 1970 & $\mathrm{x}$ & ? & & & & & & \\
\hline & Domasia? spp. & $\mathrm{x}$ & & & $\mathrm{x}$ & & & & \\
\hline & Domasia trispinosa Downie 1960 & & $\mathrm{x}$ & & & & & $\mathrm{x}$ & \\
\hline & Domasia trispinosa Downie 1960 - D. elongata Downie 1960 grp. & $\mathrm{x}$ & & & $\mathrm{x}$ & & & & \\
\hline & Dorsennidium europaeum (Stockmans \& Willière) Sarjeant \& Stancliffe 1994 & $\mathrm{x}$ & $\mathrm{x}$ & & $\mathrm{x}$ & & & $\mathrm{x}$ & \\
\hline & Eupoikilofusa rochesterensis Cramer ex Eisenack et al . 1976 & $\mathrm{x}$ & & & & & & & \\
\hline & Eupoikilofusa striatifera (Cramer) Cramer 1970 & $\mathrm{x}$ & (?) & & & & & & \\
\hline & Helosphaeridium? spp. & $\mathrm{x}$ & $(\mathrm{x})$ & & & & & & \\
\hline & Leiofusa spp. & & & & $\mathrm{x}$ & & & & \\
\hline & Leiofusa tumida Downie 1959 & & & & & & & $\mathrm{x}$ & \\
\hline & Leiofusa aff. tumida Downie 1959 & & & & $\mathrm{x}$ & & & & \\
\hline & Lophosphaeridium spp. & $\mathrm{x}$ & $\mathrm{x}$ & & $\mathrm{x}$ & & & $\mathrm{x}$ & $\mathrm{x}$ \\
\hline & Micrhystridium intonsurans (Lister) Dorning 1981 & & & & & & & $\mathrm{x}$ & \\
\hline & Micrhystridium spp. & $\mathrm{x}$ & $\mathrm{x}$ & & $\mathrm{x}$ & & & & $\mathrm{x}$ \\
\hline & Micrhystridium stellatum Deflandre 1945 & $\mathrm{x}$ & $\mathrm{x}$ & & $\mathrm{x}$ & & & & \\
\hline & Moyeria cabottii (Cramer) Miller \& Eames 1982 & $\mathrm{x}$ & $\mathrm{x}$ & $\mathrm{x}$ & $\mathrm{x}$ & & & & \\
\hline & Multiplicisphaeridium cladum Downie 1963 & & & & & & & $\mathrm{x}$ & \\
\hline & Multiplicisphaeridium spp. & $\mathrm{x}$ & $\mathrm{x}$ & & $\mathrm{x}$ & & & & \\
\hline & Navifusa? spp. & $\mathrm{x}$ & & & & & & & \\
\hline & Oppilatala spp. & $\mathrm{x}$ & & & & & & & \\
\hline & Salopidium granuliferum (Downie) Dorning 1981 & & $(\mathrm{x})$ & & & & & $\mathrm{x}$ & \\
\hline & Salopidium? spp. & $\mathrm{x}$ & & $\mathrm{x}$ & & & & & \\
\hline & Schismatosphaeridium perforatum Staplin, Jansonius \& Pocock 1965 & $\mathrm{x}$ & $(\mathrm{x})$ & & & & & $\mathrm{x}$ & \\
\hline & sphaeromorph acritarchs & $\mathrm{x}$ & $\mathrm{x}$ & $\mathrm{x}$ & $x$ & & $\mathrm{x}$ & $\mathrm{x}$ & $\mathrm{x}$ \\
\hline & sphaeromorph acritarchs (large, thick-walled) & $\mathrm{x}$ & $\mathrm{x}$ & $\mathrm{x}$ & $\mathrm{x}$ & & & & $\mathrm{x}$ \\
\hline & Tunisphaeridium tentaculaferum? (Martin) Cramer 1970 & $\mathrm{x}$ & & & & & & & \\
\hline & Tylotopalla caelamenicutis Loeblich 1970 & $\mathrm{x}$ & & & & & & & \\
\hline & $\begin{array}{l}\text { Tylotopalla deerlijkianum (Martin) Martin } 1978 \text { - } \\
\text { T. astrifera Kiryanov } 1978 \text { grp. } \\
\end{array}$ & $\mathrm{x}$ & $\mathrm{x}$ & ? & ? & & & & \\
\hline & Tylotopalla? spp. & $\mathrm{x}$ & & $\mathrm{x}$ & $\mathrm{x}$ & & & & \\
\hline & Tylotopalla aff. tappaniae Kiryanov 1978 & $\mathrm{x}$ & & $\mathrm{x}$ & & & & & \\
\hline & Veryhachium sp. (5 processes) & $\mathrm{x}$ & $(\mathrm{x})$ & & $\mathrm{x}$ & & & & \\
\hline & Veryhachium spp. & $\mathrm{x}$ & & & $\mathrm{x}$ & & & & \\
\hline & Veryhachium trispinosum (Eisenack) Stockmans \& Willière 1962 & $\mathrm{x}$ & $(\mathrm{x})$ & & & & & $\mathrm{x}$ & $\mathrm{x}$ \\
\hline & Visbysphaera brevifurcata (Eisenack) Lister 1970 & $\mathrm{x}$ & & ? & & & & & \\
\hline & Visbysphaera connexa Le Hérissé 1989 & $\mathrm{x}$ & $(\mathrm{x})$ & & & & & & \\
\hline & Visbysphaera dilatispinosa (Downie) Lister 1970 & $\mathrm{x}$ & & & $\mathrm{x}$ & & & & \\
\hline & Visbysphaera erratica brevis Le Hérissé 1989 & $\mathrm{x}$ & & $\mathrm{x}$ & & & & & \\
\hline & Visbysphaera gotlandica? (Eisenack) Kiryanov 1978 & $\mathrm{x}$ & & & & & & & \\
\hline & Visbysphaera microspinosa (Eisenack) Lister 1970 & $\mathrm{x}$ & & ? & & & & & \\
\hline & Visbysphaera aff. oligofurcata (Eisenack) Lister 1970 & $\mathrm{x}$ & & & & & & & \\
\hline & Visbysphaera pirifera (Eisenack) Lister 1970 & & & & & & & $\mathrm{x}$ & \\
\hline & Visbysphaera spp. & $?$ & $\mathrm{x}$ & $?$ & $?$ & & & & \\
\hline$\pi$ & Ancyrochitina spp. & $?$ & $\mathrm{x}$ & & $?$ & & & & \\
\hline N & Conochitina aff. granosa Laufeld 1974 & & & & $\mathrm{x}$ & & & & \\
\hline 㕩 & Conochitina spp. & $\mathrm{x}$ & ? & & $\mathrm{x}$ & & & $\mathrm{x}$ & \\
\hline $\bar{u}$ & chitinozoa & $\mathrm{x}$ & & $\mathrm{x}$ & $\mathrm{x}$ & & & & \\
\hline & scolecodonts & $\mathrm{x}$ & $\mathrm{x}$ & $\mathrm{x}$ & & & & $\mathrm{x}$ & $\mathrm{x}$ \\
\hline & Cheilotetras caledonica Wellman \& Richardson 1993 & & & $\mathrm{x}$ & & & $\mathrm{x}$ & & \\
\hline & Dyadospora murusattenuata Strother \& Traverse 1979 & & & & & & $\mathrm{x}$ & & \\
\hline o & dyads & ? & & & ? & & $\mathrm{x}$ & & \\
\hline$\frac{0}{0}$ & Laevolancis divellomedia (Chibrikova) Burgess \& Richardson 1991 & $\mathrm{x}$ & $\mathrm{x}$ & $\mathrm{x}$ & $\mathrm{x}$ & & $\mathrm{x}$ & & \\
\hline$\frac{0}{0}$ & Laevolancis plicata Burgess \& Richardson 1991 & & & & & & $\mathrm{x}$ & & \\
\hline 芩 & Pseudodyadospora petasus Wellman \& Richardson 1993 & & & & & & $\mathrm{x}$ & & \\
\hline $\bar{u}$ & Rimosotetras problematica Burgess 1991 & & $?$ & & & & ? & & \\
\hline & tetrads & $\mathrm{x}$ & & $\mathrm{x}$ & ? & & & & \\
\hline & Tetrahedraletes medinensis Strother \& Traverse 1979 & & $\mathrm{x}$ & $\mathrm{x}$ & & & $\mathrm{x}$ & & $\mathrm{x}$ \\
\hline & Ambitisporites avitus Hoffmeister 1959 & & & & & & $\mathrm{x}$ & & \\
\hline 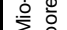 & Ambitisporites dilutus (Hoffmeister) Richardson \& Ioannides 1973 & & & & & & $\mathrm{x}$ & & \\
\hline & Ambitisporites spp. & & ? & & & & & $\mathrm{x}$ & \\
\hline & plant cuticle & & & & & & $\mathrm{x}$ & & \\
\hline & Porcatitubulus (banded tube) & & & & & & $\mathrm{x}$ & & \\
\hline
\end{tabular}

